\title{
Native Subsistence Fisheries: A Synthesis of Harvest Studies in Canada
}

\author{
FIKRET BERKES ${ }^{1}$
}

\author{
(Received 20 January 1989; accepted in revised form 15 May 1989)
}

\begin{abstract}
Subsistence fisheries, as distinct from commercial and recreational, exist throughout much of the Canadian North and satisfy local needs for fish protein. These fisheries have been investigated quantitatively only since the 1970s. Many of these studies are in the "grey literature"; methods of study and reporting are not standardized, and interpretation of data is often problematic. Nevertheless, some generalizations can be offered from a preliminary survey of harvest study data from 93 communities and from 10 regional studies representing Labrador, Quebec, Ontario, Manitoba, Saskatchewan, British Columbia and the Northwest Territories. The data indicate a wide range of harvest values, clustering at about $60 \mathrm{~kg}$ of whole fish per capita per year. If these data are representative, there is a significant subsistence fishery sector important for the local economies of hundreds of communities. Most of these fisheries are not being reported in fishery statistics, nor are they being monitored and assessed.
\end{abstract}

Key words: subsistence, fisheries, native people, native harvest surveys, resource management policy, co-management, Arctic, Subarctic

RÉSUMÉ. La pêche de subsistance, par opposition à la pêche commerciale ou sportive, existe dans presque tout le Grand Nord canadien et satisfait aux besoins de la population locale en protéines de poisson. Cette pêche n'a été étudiée de façon quantitative que depuis de la «littérature grise"; les méthodes d'étude et de rapport ne sont pas standardisées et l'interprétation des données est souvent problématique. On peut cependant présenter certaines généralisations à partir d'une étude préliminaire des données sur les prises effectuées dans 93 communautés et à partir de 10 études régionales représentant le Labrador, le Québec, l'Ontario, le Manitoba, la Saskatchewan, la Colombie-Britannique et les Territoires du Nord-Ouest. Ces données montrent une grande différence dans les quantités de poisson pêché, quantités qui se situent pour la plupart autour de $60 \mathrm{~kg}$ de poisson entier par habitant et par an. Si ces données sont représentatives, il existe un secteur de pêche de subsistance non négligeable et important pour l'économie locale de centaines de communautés, mais on n'en tient pratiquement pas compte dans les statistiques sur la pêche et il n'est ni contrôlé ni évalué.

Mots clés: subsistance, pêche, aborigènes, relevés des prises effectuées par les aborigènes, politique de gestion des ressources, cogestion, arctique, subarctique

Traduit pour le journal par Nésida Loyer.

\section{INTRODUCTION}

There is a considerable amount of scattered information about subsistence fisheries, but relatively little of this may be found in the technical literature on fisheries, perhaps partly because the science to deal with such fisheries is not well developed. It is difficult to investigate and quantify subsistence fisheries, defined here as "local, non-commercial fisheries, oriented not primarily for recreation but for the procurement of fish for consumption of the fishers, their families and community" (Berkes, 1988).

Yet studies in Alaska indicate that subsistence fisheries constitute a significantly large, locally important sector (Andrews, 1989; Wolfe and Walker, 1987). Regarding the Canadian North and the mid-North, information remains scattered. There has been one attempt to summarize quantitative information (Berkes, 1983), and a comprehensive review is available on the methodology of native harvest surveys on wildlife and fish (Usher and Wenzel, 1987).

Subsistence fisheries, as defined above, no doubt occur outside the North American North, in areas with non-native populations as well. Indeed, food-oriented local fisheries in parts of the Great Lakes (Stoffle et al., 1983) and the United States Northeast (Belton et al., 1986) have come to the attention of researchers concerned with the unregulated intake of pollutants such as PCBs in fish obtained in these areas. While important topics in their own right, these fisheries, Third World subsistence or artisanal fisheries (Emmerson, 1980) and food fisheries in the Eurasian North have been left outside the scope of this paper.
The task of this paper is to provide an overview of Canadian subsistence fisheries in the North and the mid-North, a survey of the results of quantitative studies of these fisheries, and the context within which subsistence fisheries may be evaluated. The paper also examines the usefulness of this compendium as a basis for analysis and management.

Implications of the new developments and findings in this neglected fishery sector were discussed with the fisheries science community at the Subsistence Fisheries Symposium, American Fisheries Society 1988 Annual Meetings in Toronto and followed up at the 1989 meetings in Anchorage. To a large extent, the subsistence fishery is not being reported in fishery statistics, monitored, assessed or regulated. If there is indeed a significant subsistence fishery sector, this has implications for public policy regarding resource management, allocation, impact assessment and regional economic planning.

\section{SUBSISTENCE FISHERIES IN CANADA}

\section{Historical Development}

The first scientific surveys of subsistence fisheries go back at least to the 1940s. Rawson (1947) surveyed the communities around Great Slave Lake and estimated a lake-wide fishery of about $700 \mathrm{t} / \mathrm{yr}$ and a per capita consumption of some $75 \mathrm{~kg}$. At the more remote Great Bear Lake, the lakewide fishery was estimated at $900 \mathrm{t} / \mathrm{yr}$, and the harvest for direct human consumption at $3 \mathrm{t}$ per family per year (Miller, 1947). 
Until the 1970s, information on fish and wildlife harvests that is, estimates of the quantity of a particular species taken in a specific area or by a specific group of people over a specific period of time (Usher and Wenzel, 1987) - came from three sources: investigations by anthropologists and other field researchers, "area economic surveys" (reviewed by Lotz, 1976) and administrative data sets (reviewed by Usher and Wenzel, 1987).

In the 1970s, comprehensive surveys carried out cooperatively with native organizations, often covering large areas and many communities and obtaining harvest data on the basis of information from the harvesters, became common. The first attempt at such surveys seems to be that of Salisbury et al. (1972) in the James Bay area; this study has been superseded by the surveys jointly carried out by the federal and provincial governments, the Inuit of northern Quebec and the Cree of James Bay. Carried out under the James Bay and Northern Quebec Agreement of 1975, these JBNQ Native Harvest Research surveys (henceforth NHR) have been the basis of many similar surveys elsewhere (NHR, 1982a,b).

\section{Treatment of the Data}

This compilation of quantitative estimates of subsistence fisheries should be taken as a "preliminary synthesis" because it is no doubt incomplete and only a first approximation in summarizing a vast "grey literature" (Usher and Wenzel, 1987). In compiling and standardizing the data, the following guidelines were used.

The data were summarized in the simplest, least interpreted form possible, in $\mathrm{kg}$ per capita per year of round (whole) weight units. The total community harvest (not food weight or consumed weight) was taken, from which commercial catches (if any) and harvest specifically identified as dog food (if any) were subtracted. The community harvest figure was then divided by the number representing the total resident (not total registered) native population (including children) to give a per capita figure.

In cases in which the harvesters included non-native people, the population figure as supplied by the investigator was used (e.g., Labrador, Usher, 1982). In cases in which the results were given in units other than "whole weights," the investigators' own conversion factors were used to backcalculate whole weights. Or else data were converted by using the relationship "edible weight $=0.70$ whole weight." In instances in which the author supplied data on fish numbers (and not weights), mean fish weights were taken from
NHR (1982a) and NHR (1982b), which provide data from across the Canadian North, not only from James Bay and northern (arctic) Quebec.

Data sources used in Figure 1 were limited to studies in which there was at least a recognizable methodology for collecting information. Sources that included information only in passing and those in which data collection details year, community name, population size - could not be confirmed were left out of the compilation. However, no attempt was made to evaluate each of the accepted sources critically; this has been done by Usher and Wenzel (1987).

Since the studies in this paper do not follow a consistent methodology, the data from each region or community are not strictly comparable. This is an unavoidable shortcoming of a synthesis of such a field of study, and this qualification should be kept in mind when interpreting the overall results. However, at least one set of results (Chisasibi, James Bay) from a questionnaire and diary-based harvesting study have been extensively field-tested and confirmed (Berkes, 1983).

\section{Regional Studies}

Table 1 provides a summary of regional fish harvest studies across Canada. The Labrador study included Inuit people as well as "settlers," non-native people who share a native lifestyle. The northern Quebec study was summarized using the more conservative data (year 1978) from this five-year investigation; the final summary report was not available at the time of writing. The James Bay data were available as a five-year average (NHR, 1982b), but the 1974-75 data were used here as the most representative year because there were development-related perturbations after that date (Berkes, 1982).

The Huron-Georgian Bay study covered the RobinsonHuron Treaty region. Much of this harvest came from one large reserve on Manitoulin Island, Wikwemikong, which controlled the fishing area of the east coast of the island and which also carried out commercial fishing. The Manitoba figure was a province-wide rough estimate. The population figure of 35000 refers to the whole province; the population of northern native communities was given as 31500 (Green and Derksen, 1984).

The Saskatchewan estimate was based on harvests of licenseholders and their families (pop. 1923) projected to the entire province (total native population at the time, 71 047). The subsistence harvest is no doubt distributed beyond the immediate families of license holders and likely shared by the

TABLE 1. A summary of regional studies of native subsistence fisheries in Canada (see text for explanatory notes)

\begin{tabular}{|c|c|c|c|c|c|}
\hline Region & Year & Fish harvest (kg) & Population & $\begin{array}{l}\text { Per capita } \\
\text { (kg/year) }\end{array}$ & Reference \\
\hline Labrador & 1979 & 170909 & 2068 & 83 & Usher (1982) \\
\hline Northern Quebec (Inuit) & 1978 & 233000 & 3981 & 59 & NHR (1982a) \\
\hline James Bay area, Quebec & $1974-75$ & 320000 & 6267 & 51 & NHR (1982b) \\
\hline Huron-Georgian Bay, Ontario & 1982 & 306818 & 4967 & 62 & Armstrong (1983) \\
\hline Manitoba & 1975 & 1700000 & 35000 & 50 & Green and Derksen (1984) \\
\hline \multirow[t]{2}{*}{ Saskatchewan } & 1985 & 284076 & 1923 (sample) & 148 & Murray and Clouthier (1986) \\
\hline & & 1850000 & 71047 (tot. pop.) & 26 & \\
\hline British Columbia & 1980 & 2270000 & 43000 & 53 & Pearse (1982) \\
\hline Mackenzie Valley, N.W.T. & 1972 & 374954 & 7485 & 50 & Bissett (1974) \\
\hline Baffin Region, N.W.T. & 1982 & 370000 & 6889 & 54 & Donaldson (1984) \\
\hline Keewatin Region, N.W.T. & $1981-82$ & 161079 & 3769 & 43 & Gamble (1984) \\
\hline
\end{tabular}


TABLE 2. Per capita harvests by community; harvest figures were standardized as outlined in the section on data treatment

\begin{tabular}{|c|c|c|c|c|c|c|c|}
\hline & $\begin{array}{l}\text { Population } \\
\text { (year) }\end{array}$ & $\begin{array}{c}\text { Harvest } \\
(\mathrm{kg} / \text { capita/yr) }\end{array}$ & Reference & & $\begin{array}{l}\text { Population } \\
\text { (year) }\end{array}$ & $\begin{array}{c}\text { Harvest } \\
\text { (kg/capita/yr) }\end{array}$ & Reference \\
\hline 1. Inukjuak, Quebec & 687 (1978) & 118 & NHR (1982a) & 57. Frobisher Bay & 1470 & 11 & $"$ \\
\hline 2. Akulivik & 221 & 168 & $"$ & 58. Grise Fiord & 99 & 37 & $"$ \\
\hline 3. Sugluk & 410 & 62 & $"$ & 59. Hall Beach & 339 & 67 & $"$ \\
\hline 4. Wakeham Bay & 304 & 72 & $"$ & 60. Igloolik & 716 & 73 & $"$ \\
\hline 5. Koartuk & 150 & 34 & $"$ & 61. Lake Harbour & 214 & 54 & $"$ \\
\hline 6. Payne Bay & 272 & 144 & " & 62. Nanisivik & 110 & 20 & $"$ \\
\hline 7. Aupaluk & 56 & 191 & $"$ & 63. Pangnirtung & 789 & 53 & $"$ \\
\hline 8. Leaf Bay & 105 & 286 & $"$ & 64. Pond Inlet & 663 & 50 & $"$ \\
\hline 9. Kuujjuak & 902 & 64 & $"$ & 65. Resolute Bay & 144 & 8 & $"$ \\
\hline 10. George River & 355 & 175 & $"$ & 66. Sanikiluaq & 364 & 74 & $"$ \\
\hline 11. Great Whale River (Inuit) & 466 & 26 & $"$ & 67. Outpost camps & 126 & 148 & $"$ \\
\hline 12. Fort George (Inuit) & 49 & 48 & $"$ & 68. Baker Lake, N.W.T. & $992(1981-82)$ & 41 & Gamble (1984) \\
\hline 13. Fort George (Cree) & $1525(1974 / 75)$ & 62 & NHR (1982b) & 69. Chesterfield Inlet & 204 & 8 & " \\
\hline 14. Great Whale (Cree) & 352 & 22 & " & 70. Coral Harbour & 376 & 44 & $"$ \\
\hline 15. Paint Hills & 628 & 34 & $"$ & 71. Eskimo Point & 1005 & 19 & $"$ \\
\hline 16. Eastmain & 306 & 26 & $"$ & 72. Rankin Inlet & 653 & 62 & " \\
\hline 17. Rupert House & 910 & 10 & $"$ & 73. Repulse Bay & 338 & 33 & $"$ \\
\hline 18. Mistassini & 1725 & 62 & $"$ & 74. Whale Cove & 201 & 156 & $"$ \\
\hline 19. Waswanipi & 719 & 94 & " & 75. Aklavik & $677(1973)$ & 66 & Tessop et al. (1974) \\
\hline \multirow[t]{2}{*}{ 20. Dokis, Ontario } & $153(1982)$ & 90 & Armstrong & 76. Arctic Red River & $96(1973)$ & 613 & 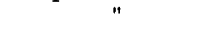 \\
\hline & & & (1983) & 77. Lac La Martre & $160(1972)$ & 401 & Bond (1973) \\
\hline 21. Henvey Inlet & 23 & 19 & " & 78. Resolute/Kuvinaluk & $179(1976)$ & 45 & Kemp et al. \\
\hline 22. French River & 84 & 27 & $"$ & & & & $(1977)$ \\
\hline 23. Magnetawan & 40 & 12 & $"$ & 79. Old Crow, Yukon & 142 (1973) & 96 & Stager (1974) \\
\hline 24. Mississauga & 178 & 58 & $"$ & 80. Fort Good Hope, N.W.T. & $500(1982)$ & 125 & Fort Good \\
\hline 25. Nipissing & 354 & 81 & " & & & & Hope Band \\
\hline 26. Parry Island & 176 & 29 & $"$ & & & & Council \\
\hline 27. Serpent River & 145 & 17 & $"$ & & & & (unpubl.) \\
\hline 28. Shawanaga & 69 & 42 & $"$ & 81. Lake of the Woods, Ont. & $1667(1980-82)$ & 33 & Usher (1987) \\
\hline 29. Sheguiandah & 73 & 49 & $"$ & 82. Teslin, Yukon & $187(1984)$ & 81 & Duerden \\
\hline 30. Sheshegwaning & 82 & 10 & $"$ & & & & (1986) \\
\hline 31. Spanish River & 644 & 16 & " & 83. Old Crow, Yukon & $165(1983-84)$ & 15 & Murphy \\
\hline 32. Sucker Creek & 175 & 30 & $"$ & & & & (1986) \\
\hline 33. Thessalon & 19 & 9 & $"$ & 84. Ross River, Yukon & 243 (1982) & 83 & Dimitrov and \\
\hline 34. West Bay & 518 & 20 & $"$ & & & & Weinstein \\
\hline 35. Whitefish Lake & 170 & 22 & $"$ & & & & (1984) \\
\hline 36. Whitefish River & 233 & 30 & $"$ & 85. Nain, Labrador & 890 (1979) & 68 & Usher (1982) \\
\hline 37. Wikwemikong & 1829 & 209 & " & 86. Hopedale & 420 & 72 & " \\
\hline \multirow[t]{3}{*}{ 38. Pukatawagan, Manitoba } & 1025 & 53 & Green and & 87. Makkovik & 320 & 87 & $"$ \\
\hline & & & Derksen & 88. Postville & 183 & 135 & $"$ \\
\hline & & & (1984) & 89. Rigolet & 255 & 107 & $"$ \\
\hline 39. South Indian Lake & 669 & 34 & " & 90. Black Lake, Sask. & $675(1985)$ & 74 & B. Smith, pers. \\
\hline 40. Nelson House & 1360 & 17 & $"$ & & & & comm. from \\
\hline 41. Brochet & 994 & 17 & $"$ & & & & data of \\
\hline 42. Little Grand Rapids & 518 & 51 & $"$ & & & & Murray and \\
\hline 43. Pauingassi & 194 & 50 & " & & & & and Clouthier \\
\hline 44. St. Therese & 933 & 51 & $"$ & & & & (1986) \\
\hline 45. Garden Hill & 1280 & 33 & $"$ & 91. Buffalo River & 429 & 54 & $"$ \\
\hline 46. Wasagamach & 417 & 51 & $"$ & 92. Patuanak & 643 & 33 & $"$ \\
\hline 47. Red Sucker & 281 & 33 & $"$ & 93. Turner Lake & 413 & 65 & $"$ \\
\hline 48. Oxford House & 828 & 51 & $"$ & 94. Pinehouse, Sask. & $671(1983-84)$ & 109 & Northern \\
\hline 49. Gods Lake & 1018 & 54 & $"$ & & & & Village of \\
\hline 50. Shamattawa & 425 & 31 & $"$ & & & & Pinehouse \\
\hline 51. Granville Lake & 121 & 31 & $"$ & & & & (1987) \\
\hline 52. Cross Lake & 2174 & 52 & $"$ & 95. Sanikiluaq, N.W.T. & 435 (1985) & 86 & Quigley and \\
\hline 53. Arctic Bay, N.W.T. & 345 (1982) & $\begin{array}{r}58 \\
(1984)\end{array}$ & Donaldson & & & & $\begin{array}{c}\text { McBride } \\
\text { (1987) }\end{array}$ \\
\hline 54. Broughton Island & 367 & 125 & $"$ & 96. Makkovik, Labrador & $333(1980-81)$ & 29 & Mackey and \\
\hline 55. Cape Dorset & 737 & 68 & $"$ & & & & Orr (1987) \\
\hline 56. Clyde River & 434 & 49 & $"$ & & & & \\
\hline
\end{tabular}

portion of the native population (27 457) living in central and northern parts of the province. If so, the per capita harvest may be more like $50 \mathrm{~kg}$, obtained by dividing the harvest in these parts (1 $312479 \mathrm{~kg}$ ) by the local population. Data from one northern and three central zone communities with good statistical coverage indicate a mean of $56 \mathrm{~kg}$ and a range of 33$74 \mathrm{~kg}$ (B. Smith, pers. comm. 1988).
The British Columbia figure is based, not on harvesting surveys, but on federal government statistics on the coastal fishery, mainly on salmon (Pearse, 1982). The report indicated that some 25000 people benefited from this harvest (Pearse, 1982). But because of extensive food-sharing networks so common among native peoples, E. Pinkerton (pers. comm. 1987), who has done work with native fisheries, 
estimated that about three-quarters of the total native population of 57000 may be consuming it; Table 1 follows Pinkerton's estimate. In a more recent publication, Pearse (1988) has updated his B.C. native fishery estimate to $3062 \mathrm{t}$ / yr, but no details were given.

The Mackenzie Valley study was one of the earlier surveys, and harvests by community were difficult to ascertain from the results. Together with the Keewatin Region survey (in which more complete data were available for 1981-82 than for 1982-83) and the Baffin Region survey (a multi-year study for which the final report was not available at the time of writing), the Northwest Territories (N.W.T.) surveys add up to a subsistence harvest of $906 \mathrm{t} / \mathrm{yr}$. There have also been N.W.T.wide estimates of $1136 \mathrm{t}$ (Science Advisory Board, 1980) and 1300 tons (Pearse, 1988), but no details of calculations were given. The N.W.T. estimates will be updated by means of the Government of N.W.T., Renewable Resources Department survey, Federal Department of Fisheries and Oceans surveys and the Inuvialuit harvest study, all of which were in progress at the time of writing.

\section{Harvests by Community}

Regional studies are useful in providing information over large areas, but averaging several communities masks the differences among them. Table 2 provides community-bycommunity information on subsistence fish harvests, converted to common units. The table includes all available community data from the regional studies referred to in Table 1 , plus a number of studies based on one or a small number of communities, for a total of 96 entries. The table excludes a

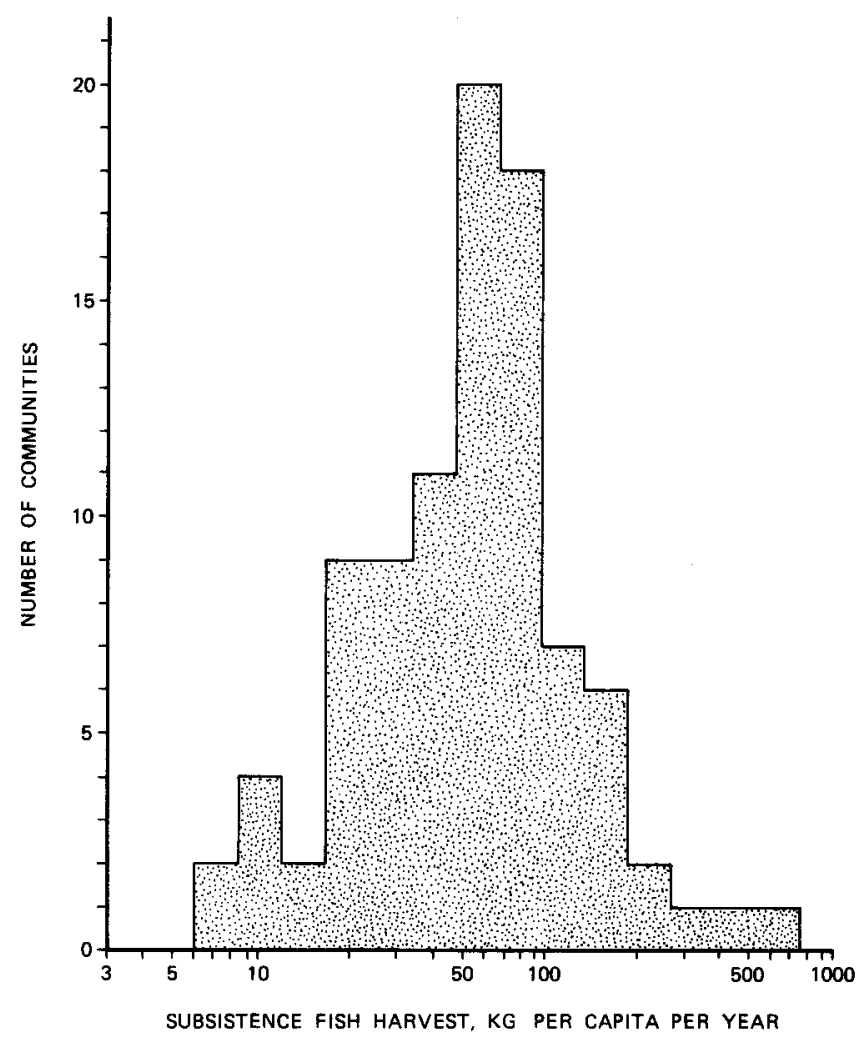

FIG. 1. Subsistence fish harvests (kg whole weights per capita per year) in 93 communities across the Canadian North and mid-North. For details and references, see Table 2 .

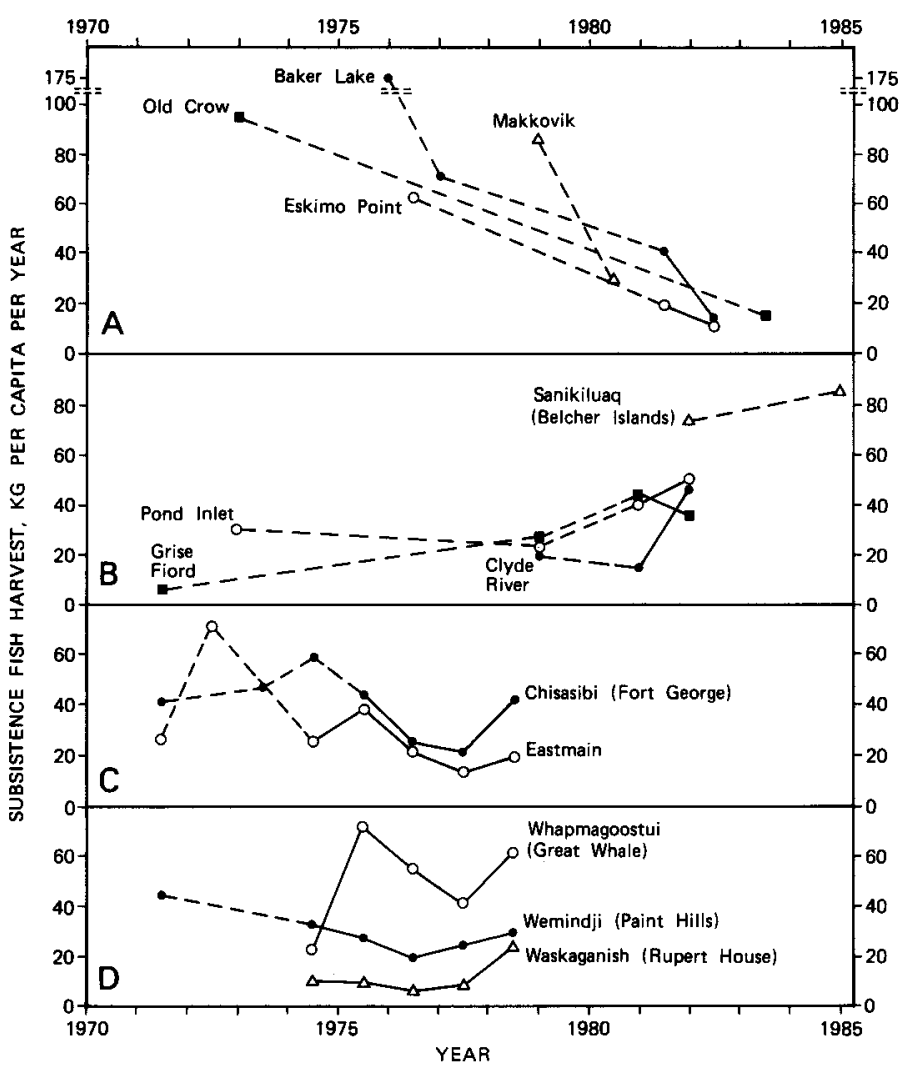

FIG. 2. Time trends in subsistence fish harvests. Solid lines indicate consecutive year coverage with standardized methodology. Sources - A: Stager (1977); Interdisciplinary Systems (1978); Gamble (1984); Stager (1974); Murphy (1986); McEachern (1978); Usher (1982); Mackey and Orr (1987). B: Riewe (1977); Finley and Miller (1980); Donaldson (1984); Quigley and McBride (1987). C and D: Salisbury et al. (1972); Weinstein (1976); NHR (1982b).

number of older studies in cases in which more recent data exist. Three communities, however, are entered twice where two different studies are available, both relatively recent. The total number of communities represented is 93 .

Figure 1 displays these data on 93 communities. Regarding the 3 communities entered twice in Table 2 , those indicated as numbers 83,87 and 95 were left out by random selection. The presentation of results poses a problem because of wide variation. Since the range of values is about two orders of magnitude (from a low of about 6 to a high of $600 \mathrm{~kg}$ per capita per year), a log scale is used. Two-thirds of the values fall in the interval $25-110 \mathrm{~kg}$. The two highest bars represent $41 \%$ of all of the values and fall between 43 and $91 \mathrm{~kg}$. Given the nature of the data, the direct comparison of figures from different studies would not be prudent, and exacting statistical analysis of Figure 1 would not be appropriate. A figure of $60 \mathrm{~kg}$ per capita per year will be taken as a "working mean."

For several communities, a number of harvest estimates are available over a period of time. Figure 2 shows the time trends for a selection of 13 communities. Figure 2A depicts four communities with apparent trends of sharp decline; the reasons for this decline are unclear. Figure $2 \mathrm{~B}$ shows a different collection of four communities with an apparently increasing trend of per capita subsistence fish harvests. Solid (as opposed to broken) lines were used only in cases in which a community was surveyed using standardized methodology over consecutive years. 
The most consistent set of time-series data comes from James Bay area harvest studies. Leaving out the two communities most seriously affected by high mercury values in fish over the study period, Figure $2 \mathrm{C}$ and $\mathrm{D}$ show time trends for five Cree communities. The year-to-year variation seen in these graphs provides some indication of the risks involved in generalizing from only one year of surveys for any one community.

Extensive field studies reported elsewhere (e.g., Berkes, 1979) showed that the year-to-year variations in Chisasibi (Fort George) were not due to fluctuation in the supply of fish, but to changes in employment opportunities and the availability of other wildlife used as food. This was the case also for some other communities. For example, the low value for Great Whale in 1974-75 coincided with the community housing project, which kept many hunters-fishers in the village during that year. Once the project was over, per capita fish harvests showed a 3.5-fold increase in 1975-76.

Fish harvests in the James Bay Cree communities tend to average about one-quarter of the total subsistence food harvest (NHR, 1982b). Fish are considered a "back-up" food source, and there is evidence that the fish harvest fluctuates in a way that compensates for the availability of other, preferred wild food, which varies from year to year (e.g., geese) or shows periodic cycles (e.g., small game) (Weinstein, 1976; Berkes, 1979).

Because of the relatively reliable and abundant nature of the resource, many native groups across the North regard fish as a staple. The subsistence fishery is often the most persistent segment of the traditional wildlife-based native economy. Thus, even in areas such as the Huron-Georgian Bay region, where opportunities for hunting are very limited, fishing continues to provide relatively high returns. Native fishermen, by virtue of detailed local knowledge of fish populations and their life history, are able to harvest the fish at times when the return per unit of fishing effort is particularly high. This may be seen in Table 3, which shows that the native subsistence fishery, compared to non-native angling, was 21 times more productive per person-day of effort. When only angling was considered, native fishermen still obtained more than four times as much fish per unit of effort. High levels of harvests over short periods in native subsistence fisheries have also been observed by Berkes (1977) in James Bay and by Busiahn (1989) in Wisconsin and may be a general characteristic of these fisheries.

\section{DISCUSSION}

Native harvest surveys utilize social science methodology and depend on information from the harvesters. In this regard, subsistence survey results are not fundamentally different from statistics on commercial and recreational fishing. But they do differ from commercial fishery surveys in one important way: subsistence harvesters cannot be forced to report their harvests, accurately or otherwise; they have to be willing to cooperate.

As well, there are other potential problems in native harvest surveys, including lack of standardization of survey methodology; "strategic bias," whereby harvesters may deliberately provide inaccurate information; and "recall failure," whereby harvesters may simply be unable to report what was caught during the previous year.
TABLE 3. Comparison of the fishing success of native fisheries and non-native recreational fisheries in the Robinson-Huron Treaty area of Ontario (data from Armstrong, 1983)

\begin{tabular}{lccc}
\hline \hline & $\begin{array}{c}\text { Total catch } \\
\left(10^{6} \mathrm{~kg}\right)\end{array}$ & $\begin{array}{c}\text { Total effort } \\
\left(10^{6} \text { person-days }\right)\end{array}$ & $\begin{array}{c}\text { Catch per unit } \\
\text { of effort } \\
(\mathrm{kg} / \text { person-days })\end{array}$ \\
\hline Non-native, angling & 1.675 & 2.637 & 0.6 \\
Native, angling only & 0.045 & 0.017 & 2.6 \\
Native, all methods & 0.489 & 0.027 & 18.1 \\
$\begin{array}{l}\text { Native, all methods } \\
\text { excluding commercial } \\
\text { catch }\end{array}$ & 0.307 & 0.024 & 12.8 \\
\hline \hline
\end{tabular}

In their review of data collection and imputation methodologies, Usher and Wenzel (1987) concluded that the lack of standardization did not detract from the reliability of any one individual study. "Strategic bias" probably existed but was not systematic. "Recall failure," the authors concluded, was not a problem for most species - except for fish. The special problems in the quantification of subsistence fisheries have been dealt with by Berkes (1983), with the general conclusion that the harvest values reported in the questionnaires are probably conservative estimates.

Harvest study results were corroborated in the field for one of the surveyed communities, Chisasibi. The subsistence fishery was studied in the field by means of spot checks and participant observation techniques. Twelve family groups were monitored over several years. The overall average harvests of these groups, which were considered to be representative of the community, was $60 \mathrm{~kg}$ per capita per year over the period 1975-81 (Berkes, 1983). Note that this is higher than all but one year of the community survey results, as shown in Figure 2.

Other field studies based on observations of family groups confirm that substantial amounts of fish may be harvested. Jarvenpa (1980) reported a per capita consumption level of $112 \mathrm{~kg}$ for a group of 26 Chipewyan people at Patuanak, Saskatchewan, in 1971-72. L. Johnson (pers. comm. 1988) observed that a family group of Inuit, averaging 10 adults and children, fairly consistently harvested about 1000 arctic charr (Salvelinus alpinus) per year over the years 1974-88 at Nauyuk Lake, Kent Peninsula, near Parry Bay, N.W.T. At $2.5 \mathrm{~kg}$ per fish, this group was estimated to harvest about $250 \mathrm{~kg}$ per person per year.

The actual harvests of fish may be higher than those reported here, especially considering that some fish are also used as bait in trapping (e.g., species of suckers in the James Bay area) and that in some communities much fish may be used as dog food. Murphy (1986) estimated that three-quarters of the fish harvest was used as dog food in Old Crow in 1984 , virtually the same proportion as reported by Stager (1974). However, in most northern Canadian communities, this proportion is likely to be much lower because the use of dogs in transportation has declined in the 1960s and 1970s.

Subsistence fisheries provide Canadian native harvesters with some $60 \mathrm{~kg}$ of fish, or a potential edible weight of some $42 \mathrm{~kg}$ per person per year. This is six times higher than the average Canadian fish consumption of $7 \mathrm{~kg}$. In Alaska, the harvest figure and the discrepancy between subsistence fishermen and the general United States population is even more striking. Over the period 1980-85, Alaska Department of Fish 
and Game, Division of Subsistence, surveyed 98 communities, including about a one-third sample of the rural population of some 185000 . The overall average harvest was $104 \mathrm{~kg}$ dressed weight (or $140 \mathrm{~kg}$ whole weight) per person per year (Wolfe and Walker, 1987). This is more than twice as high as the Canadian native harvest averages summarized here. Alaska subsistence harvesters were estimated to consume 18 times more fish than the general public in the United States (Wolfe and Walker, 1987).

The higher average harvest figures in Alaska require some explanation. An intuitive ecological explanation is that the resource base may be more biologically productive on the Alaska coast than in much of the waters harvested by Canadian native groups. There is, however, an alternative explanation. Analysis of the Alaska data shows that fish almost always make up half of the total subsistence harvest, and in some regions closer to two-thirds (Wolfe and Walker, 1987). By contrast, the contribution of fish to the overall subsistence harvests in Canada is typically one-quarter to one-half in regions such as James Bay and northern Quebec (e.g., NHR, 1982b).

\section{Estimating the Size of the Subsistence Fishery Sector}

The subsistence sector is a large fishery - but how large? Bodaly (1986) provided a Canada-wide estimate by assuming an annual consumption value of $35 \mathrm{~kg}$ (equivalent of a harvest value of $50 \mathrm{~kg}$ ). If $50000-150000$ native people out of a total of some $\mathbf{4 0 0} 000$ native people, including Metis, participate in subsistence fisheries, this would give a Canadawide annual harvest total of $2500-7500 \mathrm{t}$. To put it in perspective, the subsistence fishery, according to these assumptions, would be on the order of one-tenth the size of the inland commercial fishery of Canada, which is $40000-50000 \mathrm{t} / \mathrm{yr}$ in most years.

The actual magnitude of the subsistence sector is likely to be greater than this, simply on the basis of existing harvest surveys. The regional summaries in Table 1 , incomplete as they are, add up to about 180000 people and $7750 \mathrm{t} / \mathrm{yr}$. These totals are already at the upper limit of the Canada-wide subsistence fishery estimate based on Bodaly's (1986) assumptions.

Another estimate of the total "native fisheries" is provided by Pearse (1988), based on personal communication from government fishery managers. These approximations, most of them indicated by the author to be "very rough estimates," add up to $9298 \mathrm{t}$ (British Columbia, $3062 \mathrm{t}$; Alberta, $700 \mathrm{t}$; Saskatchewan, $2050 \mathrm{t}$; Manitoba, $1000 \mathrm{t}$; Ontario, $842 \mathrm{t}$; Quebec, $216 \mathrm{t}$; Maritime provinces and Labrador, $108 \mathrm{t}$; Yukon, $20 \mathrm{t} ;$ N.W.T., $1300 \mathrm{t}$ ).

Some of these harvest values (e.g., Quebec, Ontario, Yukon) are obvious underestimates. Toappreciate the extent to which subsistence fisheries in areas such as Alberta have been underestimated for the lack of data, suffice to point out that Saskatchewan Fisheries Branch increased their estimate of the size of their subsistence fishery by an entire order of magnitude upon the completion of a detailed study of this sector (Murray and Clouthier, 1986).

Considering such recent findings and the fact that much greater numbers of people than hitherto suspected seem to be participating in subsistence fisheries, it may be reasonable to hazard a guess that Table 1 covers only about one-half of the
Canada-wide subsistence sector. If so, some 300000 northern rural people, including non-status Indians, Metis (as in Pinehouse, Saskatchewan, Table 2), and non-native people (as in Usher, 1982), may be harvesting on the order of $15000 \mathrm{t}$ of fish per year. If so, the subsistence sector may be closer to one-third of the Canadian inland fishery sector, rather than one-tenth.

\section{Policy Implications}

The data summarized here indicate that subsistence fisheries are both quantitatively significant and geographically extensive. Such fisheries are found over wide regions of the Canadian North and mid-North, and not only in a few areas. They are important for local traditional economies and culture (Keith et al., 1987; Tough, 1984).

As compared to commercial fisheries, the subsistence sector is a different kind of fishery and thus requires a different kind of management. First, since subsistence fisheries are spread over a very large area, the applicability of the usual fisheries science to this sector, with stock-by-stock assessment, is a problem. Second, even if harvest quotas and other regulations could be formulated, the enforcement of such government regulations over scattered areas would be impossible, or nearly so.

A number of innovative approaches have been suggested for subsistence fisheries management, and some have already been incorporated in government policy. These include: a) the use of local knowledge, b) the decentralization and sharing of resource management decision-making responsibility, and c) the establishment of clear priorities regarding the allocation of the resource among the subsistence, commercial and recreational fishery sectors.

Regarding local knowledge, extensive traditional knowledge obviously exists on distributions and life cycles of fish, simply because such knowledge is essential to productive fishing and was, at one time, essential to survival. As recommended by the November 1985 workshop of the Department of Fisheries and Oceans, the integration of native peoples' knowledge and scientific knowledge appears to be a useful and important resource management approach (Keith et al., 1987). But to carry out such integration appears to be a challenge that requires closer cooperation between scientist/ managers and local harvesters than has been possible in the past.

The sharing of responsibility for resource management, or co-management, is an approach examined by, among others, the Canadian Arctic Marine Conservation Strategy (Department of Fisheries and Oceans, 1987). The Strategy recommends the sharing of decision-making powers among government, native people and other stakeholders (Strategy, item 3.2.1), and provides for the recognition of cultural as well as economic benefits through the sustainable use and development of renewable resources (Strategy, item 3.3.2).

Regarding allocation priorities, policy recommendations to give subsistence fisheries precedence over commercial or sport fisheries go back at least to a 1972 Federal-Northwest Territorial task force report (Keith et al., 1987). The policy issue is an important one because the commercialization of subsistence fisheries in the past has adversely affected local subsistence economies and led to non-sustainable resource use patterns, not only in the Northwest Territories 
(Keith et al., 1987), but also in other parts of the Canadian North and mid-North, for example, in Manitoba (Tough, 1984).

In conclusion, subsistence fisheries have been virtually ignored for a long time partly because there was little published information regarding their extent and significance. Material reviewed here supports the contention that "aboriginal harvesting is not an incidental cultural remnant from the past, but a critical economic activity" (Keith et al., 1987) that continues to be important.

There is evidence from parts of the North that native subsistence users of living resources are capable of sharing management responsibility towards the sustainable use of these resources (Drolet et al., 1987). Government, however, retains the ultimate jurisdiction for resource conservation. Wherever feasible, the revitalization of community-level selfmanagement, subject to principles of conservation, has the potential to become the cornerstone of an innovative policy for subsistence fisheries management.

\section{ACKNOWLEDGEMENTS}

I am thankful to B. Smith, E. Pinkerton, R.A. Bodaly, L. Johnson and S. Murphy for their help and information. Many colleagues involved in James Bay area studies have inspired my interest in subsistence harvests and harvesters; they include $\mathrm{M}$. Breton, $\mathrm{L}$. Brooke, C. Drolet, H. Feit, I. Juniper, W. Kemp, A. Reed and M. Weinstein. I appreciate the lively interest and feedback from many at the American Fisheries Society Annual Meeting, September 1988, Toronto, and at the Freshwater Institute, DFO, Winnipeg, where preliminary versions of this paper were presented. This work has been supported by the Social Sciences and Humanities Research Council of Canada (SSHRC).

\section{REFERENCES}

ANDREWS, E.F. 1989. A low-profile subsistence fishery: Pike fishing in Minto Flats, Alaska. Arctic 42:357-361.

ARMSTRONG, E. 1983. Robinson-Huron Anishnabek fishing-hunting-trapping inventory. Robinson-Huron Treaty Region Chiefs and Councils. 509 p.

BELTON, T., ROUNDY, R., and WEINSTEIN, N. 1986. Urban fishermen: Managing the risks of toxic exposure. Environment 28(9):19-20, 30-37.

BERKES, F. 1977. Fishery resource use in a subarctic Indian community. Human Ecology 5:289-307.

1979. An investigation of Cree Indian domestic fisheries in northern Quebec. Arctic 32:46-70.

1982. Preliminary impacts of the James Bay hydroelectric project, Quebec, on estuarine fish and fisheries. Arctic 35:524-530.

1983. Quantifying the harvest of native subsistence fisheries. In: Wein, R.W., Riewe, R.R., and Methven, L.R., eds. Resources and dynamics of the boreal zone. Ottawa: Association of Canadian Universities for Northern Studies. 346-363.

1988. Subsistence fishing in Canada: A note on terminology. Arctic 41: 319-320.

BISSETT, D. 1974. Resource harvests - Hunter-trappers in the Mackenzie Valley. Task Force on Northern Oil Development, Report No.74-42. Ottawa: Information Canada. 208 p.

BODALY, R.A. 1986. Biology, exploitation and culture of coregonid fishes in Canada. Archiv fur Hydrobiologie Beiheft 22:1-30.

BOND, W.A. 1973. An investigation of the commercial fishery at Lac La Martre. Technical Report Series No. 73-5. Winnipeg: Department of the Environment. $50 \mathrm{p}$.

BUSIAHN, T. 1989. The development of state/tribal comanagement of Wisconsin fisheries. In: Pinkerton, E. Cooperative Management of Local Fisheries. Vancouver: University of British Columbia Press. 170-185.

DEPARTMENT OF FISHERIES AND OCEANS. 1987. Canadian arctic marine conservation strategy. Ottawa: DF0. 21 p.

DIMITROV, P., and WEINSTEIN, M. 1984. So that the future will be ours. A report prepared for the Ross River Indian Band, Ross River, Yukon. 393 p.
Available at the Department of Indian Affairs and Northern Development Library, Ottawa.

DONALDSON, J. 1984. 1982 Wildlife harvest statistics for the Baffin Region, N.W.T. Baffin Region Inuit Association, Technical Report No. 2. 64 p.

DROLET,C.A., REED, A., BRETON, M., and BERKES, F. 1987. Sharing wildlife management responsibilities with native groups: Case histories in Northern Quebec. Transactions of the 52nd North American Wildlife and Natural Resources Conference. 389-398.

DUERDEN, F. 1986. Teslin: The Indian village and community economy - an appraisal. Prepared for the Teslin Indian Band. Toronto: Ryerson Polytechnical Institute. $71 \mathrm{p}$.

EMMERSON, D.K. 1980. Rethinking artisanal fisheries development: Western concepts. Asian experiences. Washington, D.C.: World Bank, Staff Working Paper No. 423.97 p.

FINLEY, K.J., and MILLER, G.W. 1980. Wildlife harvest statistics from Clyde River, Grise Fiord and Pond Inlet, 1979. Prepared for Petro-Canada Explorations by LGL Ltd., Toronto. 37 p. Available from LGL Ltd., Box 457, King City, Ontario LOG IKO.

GAMBLE, R.L. 1984. A preliminary study of the native harvest of wildlife in the Keewatin Region, Northwest Territories. Canadian Technical Report of Fisheries and Aquatic Sciences No. 1282. $48 \mathrm{p}$.

GREEN, D.J., and DERKSEN, A.J. 1984. The past, present and projected demands on Manitoba's freshwater fish resources. Winnipeg: Manitoba Deptartment of Natural Resources, Fisheries MS Report No. 84-4. $171 \mathrm{p}$.

INTERDISCIPLINARYSYSTEMSLTD. 1978. Effects of exploration and development in the Baker Lake area. Prepared for Department of Indian Affairs and Northern Development. Winnipeg: Interdisciplinary Systems Ltd. Available at the Department of Indian Affairs and Northern Development Library, Ottawa.

JARVENPA, R. 1980. The trappers of Patuanak: Toward a spatial ecology of modern hunters. National Museum of Man Mercury Series, Canadian Ethnology Service Paper No. 67. 258 p.

JESSOP, C.S., CHANG-KUE, K.T.J., LILLEY, J.W., and PERCY, F.J. 1974. A further evaluation of the fish resources of the Mackenzie River Valley as related to pipeline development. Task Force on Northern Oil Development, Report No. 74-7. Ottawa: Information Canada. 95 p.

KEITH, R.F., FENGE, T., JACOBS, P., and WOODS, S. J. 1987. Arctic fisheries: New approaches for troubled waters. Northern Perspectives 15(4):1-5.

KEMP, W.B., WENZEL, G., JENSEN, N., and VAL, E. 1977. The communities of Resolute and Kuvinaluk: A social and economic baseline study. Resolute Community Council, Kuvinaluk Community, and the Polar Gas Project, Montreal. 348 p. Available at Polar Gas Project, Box 90, Commerce Court West, Toronto, Ontario M5L $1 \mathrm{H} 3$.

LOTZ, J. 1976. Area economic surveys. In: Freeman, M.M.R., ed. Inuit land use and occupancy project. Vol. 2. Ottawa: Deptartment of Indian and Northern Affairs. 23-30.

MACKEY,M.G.A., and ORR, R.D. 1987. The evaluation of household country food use in Makkovik, Labrador, July 1980-June 1981. Arctic 40:60-65.

McEACHERN, J. 1978. A survey of resource harvesting, Eskimo Point, NWT, 1975-77. Prepared for Polar Gas Project by Quest Socio-Economic Consultants Inc., Delta, B.C. 268 p. Availableat Polar Gas Project, Box 90, Commerce Court West, Toronto, Ontario M5L IH3.

MILLER, R.B. 1947. Great Bear Lake. Bulletin of the Fisheries Research Board of Canada No. 72:31-44.

MURPHY, S.C. 1986. Valuing traditional activities in the native economy: The case of Old Crow, Yukon Territory. M.A. thesis, University of British Columbia.

MURRAY, A.R., and CLOUTHIER,J.W. 1986. Involvement of people of Indian ancestry in Saskatchewan's fisheries. Regina: Saskatchewan Parks and Renewable Resources, Fisheries Branch. 224 p.

NATIVE HARVEST RESEARCH (NHR). 1982a. Research to establish present levels of native harvesting. Harvests by the Inuit of Northern Quebec. Phase II (years 1979 and 1980). Montreal: James Bay and Northern Quebec Native Harvesting Research Committee. $152 \mathrm{p}$.

$.1982 \mathrm{~b}$. The wealth of the land. Wildlife harvests by the James Bay Cree, 1972-73 to 1978-79. Quebec City: James Bay and Northern Quebec Native Harvesting Research Committee. 811 p.

NORTHERN VILLAGE OF PINEHOUSE. 1987. Pinehouse Planning Project Technical Appendix 1: Bush harvest surveys. 198 p. Available from: Pinehouse, Saskatchewan SOJ 2BO.

PEARSE, P. 1982. Turning the tide. The Commission on Pacific Fisheries Policy. Final Report. Vancouver: Deptartment of Fisheries and Oceans. $292 \mathrm{p}$. 
1988. Rising to the challenge. A new policy for Canada's freshwater fisheries. Ottawa: Canadian Wildlife Federation. $180 \mathrm{p}$.

QUIGLEY, N.C., and McBRIDE, N.J. 1987. The structure of an arctic microeconomy: The traditional sector in community economic development. Arctic 40:204-210.

RAWSON, D.S. 1947. Great Slave Lake. Bulletin of the Fisheries Research Board of Canada No. 72:45-68.

RIEWE, R.R. 1977. The utilization of wildlife in the Jones Sound region by the Grise Fiord Inuit. In: Bliss, L.E., ed. Truelove Lowland, Devon Island, Canada: A high Arctic ecosystem. Edmonton: University of Alberta Press. 623-644.

SALISBURY, R.F., ELBERG, N., HYMAN, J., and HYMAN, K. 1972. Not by bread alone: The use of subsistence resources by the James Bay Cree. Montreal: Indians of Quebec Association. 77 p. (Also as: Programme in the Anthropology of Development. Monograph No. 5. Montreal: McGill University.)

SCIENCE ADVISORY BOARD. 1980. Fish, fur and game in the Northwest Territories. Yellowknife: Department of Information, Government of the Northwest Territories. $39 \mathrm{p}$.

STAGER, J.K. 1974. Old Crow, Y.T., and the proposed northern gas pipeline. Task Force on Northern Oil Development, Report No. 74-21. Ottawa: Information Canada. $233 \mathrm{p}$.
1977. Baker Lake, NWT. A background report of its social and economic development. Prepared for the Baker Lake Settlement Council and Polar Gas Project. 203 p. Available at Polar Gas Project, Box 90, Commerce Court West, Toronto, Ontario M5L 1H3.

STOFFLE, R.W., RASCH, D.L., and JENSEN, F.V. 1983. Urban sports anglers and Lake Michigan fisheries policies. Coastal Zone Management Journal $10: 407-427$.

TOUGH, F. 1984. The establishment of a commercial fishing industry and the demise of native fisheries in Northern Manitoba. Canadian Journal of Native Studies 4:303-319.

USHER, A.J. 1987. Ontario Lake of the Woods fishery: Economic and social analysis. Transactions of the American Fisheries Society 116:352-366.

USHER, P.J. 1982. Renewable resources in the future of northern Labrador. Nain, Labrador: Labrador Inuit Association. 147 p. Available at the Department of Indian Affairs and Northern Development Library, Ottawa. and WENZEL, G. 1987. Native harvest surveys and statistics: A critique of their construction and use. Arctic 40:145-160.

WEINSTEIN, M.S. 1976. What the land provides. Report of the Fort George Resource Use Study. Montreal: Grand Council of the Crees (of Quebec). $255 \mathrm{p}$.

WOLFE, R.J., and WALKER, R.J. 1987. Subsistence economics in Alaska: Productivity, geography, and development impacts. Arctic Anthropology 24:56-81. 